\title{
Nermî ve bazı lügazlarının çözümü üzerine ${ }^{1}$
}

Ahmet ALKAN 2

APA: Alkan, A. (2020). Nermî ve bazı lügazlarının çözümü üzerine. RumeliDE Dil ve Edebiyat Araştrmaları Dergisi, (19), 541-557. DOI: 10.29000/rumelide.752509.

\section{$\ddot{O} \mathbf{z}$}

Sözlükte "Çöl faresinin, saklandığı yerin bulunmaması için yuvasını labirent gibi eğri büğrü kazması; saptırmak, sözün maksadını gizlemek, şaşırtmalı söz söylemek" anlamlarına gelen lagz kelimesinden türetilen lügaz, edebî anlamda adı gizlenen bir nesnenin özelliklerini sıralayarak ve çeşitli remz ve imalarda bulunarak cevabı karşı tarafa çağrıştırmaya dayanan şiirlere denir. Lügaz, Klasik Türk şiirinde 15. yüzyıldan itibaren kullanılmış bir türdür. Adı gizlenen bir nesnenin vasıflarını söylemek ve imada bulunmak suretiyle karşı tarafa sezdirilmesi esasına dayanır. Arap edebiyatında doğmuş, oradan Fars edebiyatına geçmiştir. Türk edebiyatına geçişi de Fars edebiyatı üzerinden olmuştur. Lügazlar temel olarak mana ve lafız lügazları olarak iki kategori altında değerlendirilmiştir. Mana lügazları lügazın çeşitli vasıflarını sıralamak suretiyle muhatabın zihninde gizlenen nesneyi çağrıştırma esasına dayanırken, lafız lügazları, şairin gizlenen nesneyi buldurma amacıyla şiirde çeşitli söz ve kelime oyunları yapmasına dayanır. Bu çalışmada lügaz türünün ortaya çıkışı, tarihi, Türk edebiyatında teşekkülü ve kullanımı hakkında kısaca bilgi verilmiştir. Devamında ise âşıklık geleneğine mensup Nermî mahlaslı şair hakkında elde edilebilen bilgiler sunulmuş ve şairin Mecmû'a-yı Hafîza adlı lügaz mecmuasında tespit edilmiş olan 48 lügazı hakkında bilgi verilmiştir. Nermînnin lügazları; vezin, nazım şekli, başlangıc ifadeleri olmak üzere şekil ve muhteva açısından incelenmiştir. Bunlardan cevabı tespit edilebilen bazı lügazların çözümü yapılarak şairin lügazlarını meydana getirirken izlediği yol üzerinde durulmuştur. Çalışmada öncelikle Nermînnin mana lügazı olarak değerlendirilen lügazlarının çözümleri verilmiş, sonrasında ise lafız lügazı özelliği taşıyan lügazları çözümlenmeye çalışılmıştır.

Anahtar kelimeler: Nermî, lügaz, klasik Türk şiiri

\section{An analysis of Nermî and some of his lügaz poems}

\begin{abstract}
The word "Lügaz" is derived from the word "lagz" which in dictionary, is defined as "Desert rat digging its nest in shape of a maze to make it hard to discover; to divert, to hide the true meaning of a word, to say obfuscatory words", and in the literary sense, it refers to the poems that aim to help the other person make associations about the answer by listing the qualities of an undisclosed object and by making implicit suggestions. Lügaz, poetic form that was used after the 15th century in Classic Turkish poetry. It's based on the idea of implying to the other person an undisclosed object by listing its qualities and making suggestions about it implicitly. It was born out of Arab literature and was adopted later by Persian literature. It was adopted by Turkish literature from the Persian literature.
\end{abstract}

Makalenin konusu olan Nermî’nin lügazları, çalışmakta olduğumuz ve tamamlanmak üzere olan Türk Edebiyatında Lügaz ve Sıdkî Efendỉnin Mecmû'a-yı Hafizza’sı adlı doktora tezinden alınmıştır. Bu makalede, Nermî’nin lügazlarının tamamına yer verilmemiş, sadece şairin lügazlarını nasıl kurduğunu ve çözüm yöntemini göstermek amacıyla bazı lügazları verilmiştir. Lügazların tam metni doktora çalışmamızda mevcuttur. Lügazların yazmadaki varak numaraları ise ilgili dipnotta verilmiştir.

2 Dr. Öğrencisi, Marmara Üniversitesi, Türkiyat Araştırmaları Enstitüsü, Türk Dili ve Edebiyatı Bilim Dalı, Eski Türk Edebiyatı ABD (İstanbul, Türkiye), ahmetalkan-1989@hotmail.com, ORCID ID: oooo-0002-5826-6632 [Makale kayıt tarihi: 11.05.2020-kabul tarihi: 20.06.2020; DOI: 10.29000/rumelide.752509] 


\begin{abstract}
Lügaz poems mainly consist of two types, namely Mana (Meaning) and Lafiz (Wording) Lügaz poems. Mana type Lügaz poems is based on the idea of creating impressions in the mind of the other person about the undisclosed object by listing certain qualities of the object while Lafiz type Lügaz poems is based on punning in the poem to help the other person guess the undisclosed object. This study provides brief information on how Lügaz poems first emerged, their adoption by Turkish literature and their usage. The study also provides information gathered on the poet known with the nickname Nermî who was from the "Aşılllk" tradition and describes 48 Lügaz poems of the poet published in the Lügaz journal named Mecmû'a-yı Hafíza. Lügaz poems of Nermî were analyzed in terms of prosody, verse types, and initial expressions. Certain Lügaz poems among these, the answer of which could be guessed were analyzed and the method used by the poet in constructing these Lügaz poems were emphasized. The study first provides analysis of Mana type Lügaz poems of Nermi which is followed by analysis of his Lafiz type Lügaz poems.
\end{abstract}

Keywords: Nermî, lügaz, classic Turkish poetry

\title{
Giriş
}

Arapça "Çöl faresinin, saklandığı yerin bulunmaması için yuvasını labirent gibi eğri büğrü kazması; saptırmak, sözün maksadını gizlemek, şaşırtmalı söz söylemek” anlamlarına gelen lagz ( لغز ) kelimesinden türetilen lügaz "Çöl faresinin yuvası, gidilmesi zor olan eğri büğrü yol; derin sır, bilmece, zekâ oyunu " gibi anlamlara gelir. Çoğulu elgâz dır. (Durmuş 2003: 221-222) Edebî anlamda ise adı gizlenen bir nesnenin remz ve ima yoluyla ve vasıflarını zikretmek suretiyle muhataba çağrıştırılarak buldurulmasına dayanan şiir türü olarak tanımlanabilir.

Lügaz bir üslup, söylem tarzı olarak doğmuş, daha sonra şairlerin şakalaşma, eğlenme ve şiirdeki kabiliyetlerini gösterme gibi amaçlarla kullandıkları edebî bir tür haline gelmiştir. Lügaz edebî bir tür olarak ilk kez Arap edebiyatında ortaya çıkmıştır. Ancak Arap edebiyatında kullanımı daha çok bilim alanında olmuştur (Toprak 2001: 98). Hz. Muhammed’in de sahabelere hurma ağacını lügaz üslubuyla sorması da ilim adamları tarafından lügaza rağbet gösterilmesinde etkili olmuştur. Lügazın ilim erbabı tarafından rağbet görmesinin bir diğer nedeni de zihni geliştirici bir özelliğinin bulunması ve eğitici bir yönünün olmasıdır. Bazı harfleri telaffuzda sorun yaşayan Ata es-Sindî̀ye, o harfleri söyletmek amacıyla arkadaşlarının şaka yollu sorduğu lügazlar ve cahiliye dönemi şairlerinden İmrü’l-Kays'ın [ö. 540 dolayları] divanında bulunan el-Bars adlı şairle yaptığı atışmalar, lügazın edebiyatta kullanımına dair ilk örneklerdir. ${ }^{3}$ Lügazın İran edebiyatında kullanımı ise daha çok saray mensuplarının dikkatini çekmek isteyen şairlerin şiirlerinde müphem ifadeler ve girift bilmeceler kullanmalarıyla olmuştur (Seyyid Gurab 1954: 11). İran edebiyatında çistan adı verilen lügazların ilk örneklerine Rûdekîde [ö. 940] rastlanır (Brown vd. 1906: 9).

Türk edebiyatında lügaz belirgin bir şekilde XV. Yüzyılda ortaya çıkmıştır. Bu tarihten önce Mevlâna’nın [ö. 1273] bir şiiri lügaz özelliklerinden bir kısmını taşısa da bu şiirin lügaz olduğuna dair kesin bir kanıt ileri sürmek güçtür. Ancak 15. Yüzyılda Ahmet Paşa [ö. 1496], Necati Bey [ö. 1509], Dede Ömer Rûşenî [ö. 1486-87], Fânî Dede [ö. 1504], Lâmiî [ö. 1531], Ahmed-i Rıdvan [ö. 1528-1538] gibi şairlerin lügaz kaleme aldıkları bilinmektedir. Divan edebiyatının Fuzûlî [ö.1556], Bağdatlı Rûhî [ö.1605], Nâbî \{ö. 1712], Şeyh Gâlib [ö. 1799] ve Nedim [0̈. 1730] gibi önemli isimlerinin de lügazları bulunmaktadır. Yine

Detaylı bilgi içib bkz. Hanna Fahuri, Divan-ı İmrü'l-Kays, Beyrut: Dârü’l-Cil, 1989, s.401-404; Ebû muhammed Abdullah b. Müslim b. Kuteybe Dineveri İbn Kuteybe, Eş-Şi’r ve'ş-Şuara, C.1, Darü's-Sekafe, Beyrut- Lübnan 1964, .652-653. 
Çağatay sahasında Ali Şir Nevâyî [ö. 1501], Sekkâkî [ö. 15.yy] ve Şîban Han [ö. 1510] gibi şairler de lügaz kaleme almışlardır. Çağatay sahasında lügaza İran edebiyatında olduğu gibi çistân denir.

Lügaz türü XV. yüzyılda ortaya çımış ve bu yüzyıldan itibaren şairler tarafindan çok rağbet görmüş; XVIII. Yüzyılda ise türün kullanımı zirveye ulaşmıştır. Lügazın XVIII. yüzyılda kullanımının artmasında döneme etki eden ve şiirde üstü kapalı ve çağrışıma dayalı bir anlam dünyası yaratan Sebk-i Hindî üslubunun da etkisi vardır. En fazla lügaz bu dönemde kaleme alınmıştır. Zaman içerisinde lügazın konu alanı genişlemiş somut eşyaların yanında rüya, hayal gibi kavramlar, tırnak kesmek gibi eylemler lügazın konusu olmuştur. Divan şiirinde yüzden fazla şair lügaz kaleme almıştır.

Lügaz türü başlangıçta daha çok kıta nazım şekli ile kaleme alınırken sonradan mesnevi nazım şekli ile kullanımı artış göstermiş ve kaleme alınan lügazların dörtte üçünden fazlasında mesnevi nazım şekli kullanılmıştır. Mesnevi ve kıta dışında gazel, nazm, kaside, tuyuğ, rubai, matla ve müfred nazım şekilleri ile de lügaz kaleme alınmıştır.

Lügazlarda vezin ile ilgili bir sınırlama yoktur. Ancak en fazla lügaz fâilâtün fâiilâtün fâi ilün ve feillâtün mefâilün fe ilün kalıpları ile kaleme alınmıștır. Fe ilâtün fe ilâtün feilün ve mefâilün mefâilün fe ûlün vezinleri de en çok lügaz yazılan diğer vezinlerdir.

Lügazda gizlenen şey genellikle bir nesnedir. Lügazlar; ol nedir kim, ol ne kim, ol ne şey kim, gibi soru ibareleriyle başlar. Sonrasında adı gizlenen nesneyi buldurmak için genellikle onun bazı özellikleri şiirde sıralanır. Sorulan şeyin canlı cansız oluşu, rengi, şekli, uzunluğu, hayvan, bitki ya da insan oluşu gibi özellikler ilk başta sıralanan ayırıcı özelliklerdir. Genel özellikleri yanında adı gizlenen nesnenin kendine has özellikleri de sıralanabilir. Bu özellikler kullanım alanı, en çok beslendiği şey, neye benzediği, en çok bulunduğu yer gibi hususlardır. Lügazın sonunda genellikle onu çözecek kişi için övgü dolu bir ödülün bulunduğu bir veya iki beyit bulunur. Burada övgünün yanında lügazın cevabını bilemeyenler için yergi de bulunabilmektedir. Bazı lügazlarda bu son beyitte lügazın cevabını içeren bir ipucu da yer alır. Bu konuya Nermî’nin lügazları çözümlenirken değinilecektir.

Lügazlar temelde mana ve lafız lügazları olarak ikiye ayrılır. Bunlardan mana lügazlarında, genellikle gizlenen nesnenin çeşitli özelliklerinin sıralanarak karşı tarafa sezdirilmesi söz konusudur. $\mathrm{Bu}$ lügazlarda bütün lügazlarda bulunan ol nedür kim, ol ne kim, ol ne şey kim, gibi soru ibareleri bölümü bulunur. Devamında gelen beyitler vasıflandırma bölümünü oluşturur. Bu bölümde sorulan nesnenin cinsi, şekli, canlı cansız oluşu, kullanım alanı gibi özellikleri sıralanır. Lügazın son beyti ise ödüllendirme ve sonuç bölümünü oluşturur. Lügazın çözümüne ait önemli ima, işaret ve ipuçları bu bölümde bulunur. Genellikle lügazı çözen kişiye övgü dolu bir ödülün verildiği ya da çözemeyenler için yerginin yapıldığı bölüm burasıdır.

Lafız lügazlarında ise gizlenen nesnenin özelliklerinin verilmesinin yanında muhatabı cevaba götüren bazı ipuçları da yer alır. Lafız lügazlarının birden çok anlamı olan kelimelerin uzak yakın anlamını kastetmek, kelimeyi anlamlı sözcüklere bölerek verilen müteradifleriyle bilinmesini istemek, iki kelimeyi bitişik yazmak, bir kelimeyi parçalayarak yazmak, hemzeli kelimeyi yumuşatmak, nokta değişikliği yapmak, kelimeyi tersinden okumak, başka bir dile nakletmek gibi ç̧şitleri vardır (Durmuş 2003: 221-222). Nermî’nin hem mana hem de lafız lügazı özelliği gösteren şiirleri bulunmaktadır. 
Klasik Türk edebiyatında lügaz gibi, gizlenen bir şeyi remz ve ima yoluyla buldurmaya dayanan bir diğer tür muammadır. ${ }^{4}$ Gizlenenen şey, insan ismiyse muamma, insan ismi dışındaki bir nesne ise lügaz olur. Ancak insan ismi üzerine kaleme alınmış lügazlar da mevcuttur. Örneğin Nâbî divanında sahabelerden Zeyd ve Amr'ın sorulduğu bir lügaz bulunmaktadır (Bilkan 1993: 1207-1208). Lügaz ve muammanın birbirine yakınlaşmasında her iki türün de beyan ilminin bir dalı olması ve maksadın gizlenerek remz ve ima yoluyla muhataba sezdirilmesi etkili olmuştur. Divanlarda rastlanan lügaz yollu muammalar, iki tür arasındaki yakınlaşmaya örnektir. Bununla beraber lügazda nesnelerin sorulması, lügazın muammadan daha fazla beyitle kaleme alınması, muammanın daha çok ebcede ve kelime oyunlarına dayanması, lügazlarda şairin mahlasının bulunması gibi özellikler muamma ve lügazı birbirinden ayırmaktadır.

Lügaz, halk edebiyatında özellikle de âşık tarzı halk şiirinde kullanılan bir tür olmuştur. Ancak lügaz, halk edebiyatında muamma ile birbirine karışmıştır. Bilkan âşı edebiyatında iki tür muamma görüldüğünü birincisi olan "askı bağlama" da gizlenen bir nesnenin kahvehanenin bir yerine asıldığını ve çözümü için ödül konduğunu ifade eder. İkinci tür muammanın ise âşıkların "karşı-beri” deyişmeleri sırasında birbirlerine söyledikleri "açma-bağlama" biçimindeki deyişmeli bağlama olduğunu söyler (Bilkan 2000: 36). Bu geleneğin adı her ne kadar muama asma olsa da sorulan şey nesne olduğu için lügaz özellikleri de bu geleneğe karışmıştır. Köprülü de muamma ve lügazın halk edebiyatında birbirine karıştığını ifade etmektedir (Köprülü 1989: 188). Bunun yanında lügaz halk edebiyatındaki bilmece türünün edebî bir şekli olarak da görülmüştür (Elçin 1993: 619-620).

Bunun dışında halk şairleri de lügaz kaleme almışlardır. Bunda XVII. Yüzyılda halk edebiyatının Klasik Türk şiirinden etkilenmiş olmasının payı vardır. Âşık Ömer [ö. 1907] divanında üç lügaz bulunmaktadır (Karasoy ve Yavuz 2015: 354; 934-935). Yine Âşılk Sümmânînin [ö. 1914] de divanında dörtlük nazım birimiyle kaleme alınmış bir lügazı bulunmaktadır (ERKAL 2015: 739-740). Çalışmadaki lügazları kaleme alan Nermî de bir halk şairidir.

\section{Nermî'nin hayatı}

Nermînnin hayatı hakkında çok fazla bilgi bulunmamaktadır. Hayatı hakkında elde edilebilen tek bilgi, bir halk şairi olduğudur. ${ }^{5}$ Niğde-Bor kaynaklı bir cönkte mahlasının geçtiği bir türkü bulunmaktadır (Bolat 2006: 148). Bu cönkte adına rastlanmasından hareketle kendisinin Niğde civarında yaşamış olması muhtemeldir. Cönkteki halk şairlerinin de büyük kısmının 18. ve 19. yüzyılda yaşamış olmaları Nermî’nin de bu yüzyılda yaşadığını düşündürmektedir. Şairin Mecmû’a-yı Hafîza adlı eserde 48 lügazı bulunmaktadır. ${ }^{6}$ Mecmû'a-yı Hafîza'da7 48 lügazının bulunması şairin divan şiirine de ilgili olduğunu göstermektedir. Bunun yanında yazdığı lügaz sayısına ve tercih ettiği nazım şekline bakarak şairin lügazla ilgili en fazla ürünün verildiği 18. ya da 19. yüzyllda yaşamış olma ihtimalinin kuvvetli olduğu söylenebilir.

\footnotetext{
Detaylı Bilgi için bkz. Bilkan, Ali Fuat (2000).Türk Edebiyatında Muamma, Akçă̆ Yayınları, 1. Baskı, Ankara. Selcan,GürçayırTeke, 'Nermî(d.?/̈̈.?)", TEIS,23.09.2013,http://www.turkedebiyatiisimlersozlugu.com/index.php?sayfa= detay\&detay=1084. [Erişim Tarihi: 12.01 .2020$]$

Mecmû'a-yı Hafiza, (Müellif: Sıdkî Mustafa), Millet Kütüphanesi AE Mnz 567, vr. 267 $; 7^{\mathrm{b}} \mathbf{2 0}^{\mathrm{a}}-271^{\mathrm{b}} ; \mathbf{2 7 1}^{\mathrm{a}}-272^{\mathrm{b}} ; \mathbf{2 7 8}^{\mathrm{b}}-28 \mathrm{O}^{\mathrm{a}}$; $309^{\mathrm{a}} ; 325^{\mathrm{a}}-326^{\mathrm{b}} ; 327^{\mathrm{a}}-328^{\mathrm{b}} ; 340^{\mathrm{b}} ; 343^{\mathrm{a}}-344^{\mathrm{b}} ; 346^{\mathrm{b}}-347^{\mathrm{a}} ; 364^{\mathrm{a}}-365^{\mathrm{b}} ; 374^{\mathrm{b}}-375^{\mathrm{b}}$.

Sıdkî Mustafa Efendi'ye (ö.1769-70) ait Arapça-Farsça-Türkçe lügazlardan oluşan bir lügaz mecmuasıdır. Millet Kütüphanesi AE Mnz 567'de Mecmû'â-yı Eş'ar ve Elgaz ismiyle kayıtlara geçmiştir. Kaynak göstermede eserin gerçek adı olan Mecmû'a-yı Hafíza kullanılmıştır.
} 


\section{Nermî’nin lügazları}

\section{Nermî’nin lügazlarında kullandığı vezinler}

Nermî, lügazlarının büyük bölümünü remel bahrinin Fâ ilâtün fâ ilātün fâ ilün kalıbı ile kaleme almıştır. Fe ilâtün feilâtün fe ilün, Feilâtün mefâilün fe ilün / fa lün, fe ilâtün feilâtün fe ilâtün fe ilün, fẩilâtün fầilâtün fầilâtün fâilün ve mefầilün mefâ îlün fe ûlün kullandı̆̆ diğer vezinlerdir.

Aşağıdaki tablo Nermî’nin lügazlarının dağılımını göstermektedir:

\begin{tabular}{|c|c|}
\hline Vezin & Lugaz \\
\hline Fâilâtün fầilātün fâiilün & 23 \\
\hline Fe ilâtün fe ilâtün fe ilün & 14 \\
\hline Fe ilâtün mefâilün feilün & 1 \\
\hline Fe ilâtün fe ilâtün fe ilâtün fe ilün & 3 \\
\hline Fâ'ilâtün fâ’ilâtün fầilâtün fâilün & 4 \\
\hline Mefầîlün mefầ̂lün fe'ûlün & 3 \\
\hline
\end{tabular}

Tablo 1. Nermî’nin lügazlarının vezinlerine göre dağılımı

\section{Nermî’nin lügazlarında kullandığı nazım şekilleri}

Nermî, lügazlarının büyük bir bölümünü mesnevi nazım şekli ile kaleme almıştır. Lügaz türünde 15. ve 16. yüzyılda kıta nazım şekli rağbet görmekteyken bu tarihten itibaren mesnevi nazım şekli önem kazanmıştır. Nermî’nin lügazlarında mesnevi nazım şeklinin ağırlıklı olmasına bakarak şairin yaşadığı yüzyılın 17 ve sonrası olduğu ileri sürülebilir. Nermî’nin 48 lügazının 42'si mesnevi, 4'ü gazel-kaside, 2'si ise kıta nazım şekli ile kaleme alınmıştır.

\section{Nermî’nin lügazlarının başlangıç ifadeleri}

Birkaç tanesi hariç şiirlerinde mahlas kullanmıştır. Nermî lügazlarına genellikle ol nedür, ol nedür kim, nedür ol gibi soru ibareleriyle başlamıştır.

\begin{tabular}{|c|c|}
\hline Ol nedür kim... & 10 \\
\hline Ol nedür... & 13 \\
\hline Ol ne... & 3 \\
\hline Nedür ol kim... & 6 \\
\hline Nedür ol... & 13 \\
\hline Bü’l-'aceb gördüm... & 1 \\
\hline nedür âyâ... & 2 \\
\hline
\end{tabular}

Tablo 2. Nermî’nin lügazlarının başlangıç ifadeleri

\section{Nermî’nin lügazlarının beyit sayıları}

Nermî, lügazlarını değişik sayılarda beyitle kaleme almıştır. Şairin lügazları daha çok beş, sekiz ve yedi beyitten oluşur. Şair 48 lügazının 13'ünü 5 beyitle, 7'sini 8 beyitle, 6 'sını 7 beyitle, 5’ini 6 beyitle, 4’ünü 
9 beyitle, 4 'ünü 10 beyitle, 4 'ünü 11 beyitle, 2'sini 4 beyitle, 1'ini 2 beyitle, 1'ini 3 beyitle, 1'ini de 12 beyitle kaleme almıştır. Sonuç olarak şairin 48 lügazının \% 27,8’i beş beyitle, \% 14,58’i 8 beyitle, \% 12,5’i 7 beyitle kaleme alınmıştır. Bu verileri düşük yüzdelerle diğer beyit sayıları takip etmektedir.

\section{Nermî'nin lügazlarının dil ve üslup özellikleri}

Şair, lügazlarında sade, anlaşılır bir dil kullanmıştır. Bunda şairin halk edebiyatına mensup olmasının payı vardır. Bunun yanında ebced ile ilgili lügazlar da kurmuştur. Lügazlarını meydana getirirken Türkçe kelimeler kullanmakla birlikte Arapça-Farsça kelimeleri de yer vermiştir. Lügazla ilgili ipuçlarında özellikle son beyitte kelimelerin Arapça ve Farsçadaki anlamlarından yararlanmıştır.

Lügazlarda gizlenen nesne ile ilgili ipuçları verilirken teşbih ve teşhis sanatlarından fazlaca istifade edilmiştir. Aşă̆ıda lügaz olarak sorulan cansız bir nesnenin özelliği teşhis sanatı ile ifade edilmiştir:

Mâderi sudur velî budur acîb

Su kaçar bundan dilâ budur garîb (Mecmû'a-yı Hafîza: v. 279ª)

Aşağıdaki beyitler ise teşbih sanatına örnektir:

Çağırur gezdigi yerlerde virür gerçi sadâ

Söyler ol murg-ı sakâ gibi velî yok zebân (Mecmû'a-yı Hafîza: v. 374ª)

Takdılar başına gûyâ ki çeleng

Sıçrar ol tağları mânend-i peleng (Mecmû'a-yı Hafîza: v. 346ª)

Şair lügazlarını oluştururken argo kelimelere de yer vermiştir:

G.tine bir uzun ağaç sokarlar

Anun fi’li bulunmaz degme erde (Mecmû'a-yı Hafîza: $325^{\mathrm{a}}-326^{\mathrm{b}}$ )

\section{Nermî’nin lügazlarının muhtevası}

Şairin lügazlarında gizlenen nesneler genellikle saz, rebab, tencere, kalem gibi somut kavramlar olmakla birlikte şair, vefâ gibi soyut bir kavramı da lügaz olarak kullanmıştır. Müzik aletleri, ev eşyaları, hayvan isimleri Nermînnin lügazlarında sorulan nesnelerdir. Nermî lügazlarını kaleme alırken ilk beyitlerde gizlenen nesne ile ilgili cinsi, şekli, kullanım alanı ilgili bilgiler vermiş, cevaba götüren asıl ipucunu son beyitlerde söylemiştir.

\section{Lügazların çözümü}

Nermî’nin lügazlarından bir kısmının mana lügazı olduğu bir kısmının da lafız lügazı olduğu görülmektedir. Mana lügazlarında muhatabı cevaba götürecek açık ve kapalı ipuçları verilirken lafız lügazlarında kelimeyi hecelere bölüp başka iki kelimelerin içinde verme, cevabı bir kelimenin içinde geçirme, ebced hesabıyla cevabı işaret etme gibi yollara başvurulduğu görülmektedir.

Nermî, mana lügazı özelliği taşıyan lügazlarında gizlenen nesneyi çağrıştırıcı ipuçları kullanmayı tercih etmiştir. Aşağıdaki lügazda tencere kelimesi çeşitli vasıflandırmalarla muhataba buldurulmaya çalışılmıştır: 
Fâilâtün fầilätün fầilün

Ol nedür gel ey birâder vir haber

Karnı acıkdıkda nân ü guşt yer

Gerçi kim işitmez ammâ gûşı var

Ey birâder sanma kim mengûşı var

Mâderi sudur velî budur acîb

Su kaçar bundan dilâ budur garîb

Yine nev tarh eyledüm bu müşkili

Nermiyâ keşf idenün oldum kulı (Mecmû'a-yı Hafîza: v. 279ª)

Tencerenin karnı acıktığından dolayı ekmek ve et yemesi, içine yemek yapmak için konan malzemelere bir göndermedir. İşitmez ancak kulağının olmasından maksat tencerenin kulplarıdır. Annesinin su olmasıyla kastedilen tencerenin demir-çelik ürünü olması ve bu maddelerin dövülürken su kullanılmasıdır. Yine suyun ondan kaçması ise aşırı ısınma sonucu suyun kaynama noktasına ulaşıp buharlaşarak tencerenin içerisinden çımasına bir göndermedir. Beyitte tencereye insansı özellikler verilmek suretiyle bir lügaz meydana getirilmiştir.

Aşağıda kuyruk kelimesinin sorulduğu lügaz da yine bir mana lügazıdır:

Feilâtün fe ilâtün fe ilâtün feilün

Nedür ol söyle ki hayvânlara mensûb bir şey

Teni bir zînet ile şöyle ki mahbûb-ı cihân

Uzanur kaddi anun gâhîce efî gibidür

Geh dolanur boyuna halkalanur hem-çü yılân

Çağırur gezdigi yerlerde virür gerçi sadâ

Söyler ol murg-ı sakâ gibi velî yok zebân

Uyar etfâl ile dâ'im yol eri yolda gerek

Düşer ardına görüp bir yüzi bedr-i rahşân

Cânı yok gerçi velî cânluya eyler hıdmet

Bend iderler gehî bî-çâreyi hem-çü arslân

Ağzı var hem dili vardur bilür isey anı sen

Tokat'ı sana virem arpalık olsun ey cân 
Başladun halt-ı kelâma çoḳ uzatdun Nermī

Bu kadar söz götürür mi bu lügaz öldün uzan (Mecmû’a-yı Hafîza: v. 374ª-375ª)

Yukarıda, muhatabı cevaba götüren ipuçlarından bazıları; gizlenen cevabın hayvanlara ait bir şey olması, boyunun yılan gibi dolambaçlı ve uzun olması, insanların ardınca giden bir şey olması, bazen başkaları tarafından bağlanması (atların kuyruğu bağlanabilir) vb. gibi özelliklerdir. Son beyitte "sözü uzattın, öldün uzan" gibi ifadelerle gizlenen şeyin uzun olduğu yine ifade edilmektedir. Parçalar birleştirildiğinde lügazın cavabı olan kuyruk, muhatabın zihninde çağrışmaktadır.

Aşağıda cevabı saz olan lügaz, çeşitli tasvirler, benzetme ve kişileştirmelerle oluşturulmuştur:

feilâtün feillâtün fe ilâtün feiliün

Nedür ol fâhişe-i bî-edeb erkânsuzdur

Konuşur ehl-i safâ ile velî cânsuzdur

Ana çengân dir idüm gördicegüm yerlerde

Yüzin ele güne göstermez o ehl-i perde

Bir kolı vardur anun hem de ayağı vardur

Sanki Aydınlıdur ol çokca kuşağı vardur

Teni başdan başa san yaradur anuy zîrâ

Bend idüp yâraların bağladılar ser-tâ-pâ

Nev'i çok her birinün vasfinı itsem uzanur

Düzdirür kendini ol fâhişe gâyet bezenür

Darb ile döğe döğe söyledür erbâbı anı

Sen de ko söyleyeni gör begüm ol söyledeni

Kürevî-şekl ise ana ne diyem benzerdür

Burnı var bir küçücük sînesi hep gözlerdür

Sîneye alur isen anı temâşâ bunda

Gezdürür eller ile âlemi bunda şunda

Tel kırarsın sakınup açma bu râzı duyılur

Ol imâm olsa müezzinle cemâat uyılur

Nermiyâ bu lügazum buldı hele itmâmı

Halka baş eğdürür ol işte temâm encâmı (Mecmû’a-yı Hafîza: v. 374) 
Lügazda saz, zevk ve safâya düşkün insanlarla konuşan müptezel bir kadına benzetilmiştir. Kendisinin perde ehli olduğu, kolu ve ayağı olduğu (âşık edebiyatındaki ayak verme geleneğine işaretle), teninin baştan başa yara olduğu ve yaralarının bağlandığı (bağlamanın perdeleri ve telleri), erbabının onu darb ile (mızraba işaretle) döve döve söylettiği vb. özellikler söylenerek muhatabı cevaba götürecek ipuçları sıralanmıştır.

Mana lügazlarına son örnek olarak rebâbın sorulduğu lügaz verilebilir:

Feilâtün fe ilâtün feiliün

Nedür ol kâmet-i mevzûn aceb

Cünbüşi kadde münâsibdür hep

Ser ile pâyı anun bir ammâ

Tepesinde gözi üç bî-pervâ

Taylasânı var anun bî-şüphe

Virmez ol ruhsatı her bir nigehe

Salınur kâmet-i mevzûnı gehî

Niçün asmışlar aceb bî-günehi

Kimi elvân ile pürdür cismi

Ne güzelce düşer anun resmi

Ayağı gerçi ağaçdur ammâ

Yere basmaz nice olur bu manâ

Bir nebâtî kocup anun belini

Bûs ider ekserî halkun elini

Gelse eyyâm-ı şitâ izlerine

Anlarun mîl çekilür gözlerine

Gösterüp kendüyi ağyâra hemân

Virmeyüp ruhsatı ol yâra hemân

Nermî pûşîdeye çek gel lügazı

Keşf olur açma kırup tel lügazı (Mecmû'a-yı Hafíza: v. 344 
Lügazda genellikle rebâbın fiziksel özellikleri verilmiştir. Boyunun uzun olması, çeşitli renklerle süslenmiş olması, elle ilgili bir nesne olması, ayağının ağaçtan olması, tepesinde üç gözünün bulunması gibi özellikler cevabı buldurmaya yönelik ipuçlarıdır.

Nermînnin lügazlarının bir kısmı da lafız lügazı olarak düzenlenmiştir. Bunlar arasında cevabı hecelere bölmek suretiyle başka kelimelerin içerisinde geçirme, ebced yoluyla cevabı sorma, cevabı bir kelimenin içerisinde geçirme, kelimenin başına veya sonuna harf ekleme çıkarma gibi yollarla oluşturulmuş lügazlar bulunmaktadır. Aşağıdaki lügazda baca sorulmuştur:

Fâilâtün fâilātün fâiilün

Ol nedür bir ucbe şahs-ı büll-aceb

Eylemiş bâlâda mesken rûz ü şeb

İrtifā'-i kadr ile rif'atlenür

Sîne germiş sûretâ ol görinür

Tamlar üstinde hemân hırsızlı̆̆ı

Fark eder mi olmasaydı gözlüğü

Aslı vardur enfe beyzer dir isem

Ben inanmazdum eger kim görmesem

Âlemi seyrân ider başdan başa

Kullanurlar bazısı gayrı işe

Dâimâ olmaz güşâde revzeni

Gösterür halka velî merd ü zeni

Murg cinsinden degül atmacadur

Bu lügaz Nermî hemân dibâcedür (Mecmû'a-yı Hafîza: v. 280 ${ }^{\text {b) }}$

Makamının irtifa kaydetmekle olduğu, damlar üzerinde olması, penceresinin her zaman açık olmaması (yazları baca delikleri kapatılır) gibi özellikler bacayı çağrıştırabilecek unsurlardır. Ancak muhatabı bacaya götüren en kesin delil son beyitte geçen dibâce (önsöz) kelimesidir. Bu kelimenin içerisinde baca kelimesi geçmekte ve bu yolla cevap muhatabın dikkatine bırakılmış olmaktadır. Burada verilen ipucuyla önceki beyitlerde verilen özellikler birleştirildiğinde lügazın cevabı netleşmektedir. Cevabın başka bir kelimenin içerisinde geçirilmesi suretiyle kurulan bir lügaz da aşă̆ıdaki perde örneğidir.

Mefâîün mefâîlün fe ûlün

Nedür ol kim vucûdı zîb ü ferde

Nümâyiş gösterür durduğı yerde 
Görinür baht-ı âşı̣ gibi mesdûd

Ki uğratmışlar anı böyle derde

Kıyâm idüp turur yârâna karşu

Velî hikmet bu kim üç çeşmi serde

Gözine mîh kakarlar ekser anun

Miyânın bend iderler gâh berde

Beyâz olmaz o şahsun cismi ekser

Yeşil al kırmızı mâî vü zerde

G.tine bir uzun ağaç sokarlar

Anun fi'li bulunmaz degme erde

Ana her kim mukâbil olur ise

Uzadur destini başlar neberde

Miyânında var anun bir ağacı

Çomak dirler ana Bektâşîlerde

Kışun kârında muhtâcız ana biz

Cibâbından sana hem yazlarda

Kişiyi hıfz ider yavuz nazardan

Hicâb eyler sana bu söz keder de

Bulunmaz bu lügaz şâlgamla turpda

Bulunur Nermiyâ gürz ü siperde (Mecmû’a-yı Hafîza: $325^{\text {a}}-326^{\text {b }}$ )

Durduğu yerde nümâyiş göstermesi, aşığın bahtına teşbihle kapalı olduğunun vurgulanması, belinin bağlanması, yeşil, kırmızı, mavi ve sarı renklerde olması, belinde çomak adı verilen bir ağaç bulunması, kışın ve yazın ihtiyaç duyulması gibi özellikler zihinde bir nesne çağrıştırmaktaysa da muhatabı, net bir cevaba götürmemektedir. Ancak bu nesnenin kişiyi kötü gözden koruduğunun söylenmesi, bu nesnenin kötü gözle insan arasına giren bir şey olduğunu düşündürmektedir. Beytin devamında hicab kelimesi geçmektedir. Hicâb "perde" demektir. Son beyitte ise muhatabı cevaba götüren en önemli ipucu verilmiştir. Bu nesnenin şalgamla turpta bulunmayıp gürz ve siperde bulunduğu ifade edilmiştir. "Siperde" ifadesinde perde kelimesi geçirilerek lügazdaki en önemli ipucu verilmiştir. Perdenin gürzde bulunması ise altı dilimli gürzlere şeş-per adı verilmesinden ileri gelir. Buradaki "per" de cevap olan perdeye bir göndermedir. Siperde ifadesinin sonundaki bulunma hali ekini gürzün bir çeşidi olan "şeşper"e eklendiğinde ortaya şeş-perde ibaresi çıar ve yine perde kelimesi başka bir kelimenin içerisinde geçirilmiş olur. 
Nermî, bazı lügazlarını cevabı hecelere bölüp art arda gelen kelimelere yerleştirmek suretiyle kurmuştur. Aşağıdaki cevabı keçi olan lügaz bu şekildeki lügazlara örnektir:

Fe ilâtün fe ilâtün fe ilün

Nedür ol zümre-i hayvândandur

Hele bir sāhib-i iz’ândandur

Hem anun şöhreti Abdu'r-rahmân

Doludur anun ile kevn ü mekân

Diseler lâyık ana Zü'l-ḳarneyn

Ki iki boynuzı var zātü’l-beyn

Takdılar başına gûyâ ki çeleng

Sıçrar ol tağları mânend-i peleng

Muğlimâne açuben ol g.tin

Mislidür g.ti kızıl meymûnın

Dört ayağ üzre ider cevlânı

Sanma bî-cân ola vardur cânı

Bu lügaz nâsı kayadan uçurur

Âşıkın ilden ile ol göçürür

Nermiyâ bey gibidür sanki hemân

Yâ çıkıpdur beden-i pâke çibân (Mecmû'a-yı Hafĩza: v. 346ª)

Hayvanlar zümresinden olması, boynuzları ile ilgili çeşitli benzetmeler yapılması Abdurrahman namıla bilinmesi, dört ayaklı olması, kayalıklarda otladığına imada bulunulması gibi özellikler muhatabı keçi cevabına yaklaştırmaktadır. Ancak asıl kuvvetli ipucu son beyitte yer almaktadır. Şâir lügazın cevabını iki heceye bölmüş ve pāke çibān kelimeleriyle keçi kelimesini lügazın içerisinde geçirmiştir.

Aşağıdaki lügazda da keçi lügazında olduğu gibi lügazın cevabı iki heceye bölünerek şiirin içerisine yerleştirilmiştir. Adı gizlenen nesnenin özellikleri olarak renginin esmer olması, cansız ancak etli olması, asılan bir şey olması, bedenini sürekli ateşe atmak istemesi, yüreğinin demirden olması, bağrının delik olması verilmiştir. Verilen özellikler zihinde içi demir olan, etli ve bir yerlere asılı bir nesneyi çağrıştırmaktadır. Aynı zamanda ateşle de içli dışlı bir nesneyi düşündürmektedir. Son beyitte geçen: "Nermiyâ açmak gibidür bu dokuz eflâke bâb" dizesinde son iki kelimede eflâke bâb kelimesi zikredilmiş ve lügazın cevabı olan kebâb (kebap) şiirin içerisinde verilmiştir. 
Fâilâtün fâiilâtün fâiilâtün fâilün

Ol nedür bir serv-kad dilber ki esmerdür katı

Sanma kim masnû' ola takdîr-i Hak'dur hilkati

Cânı yokdur gerçi kim ammâ eti var kanı var

Asılup Mansûr gibi turmuş gehî efgânı var

Nâr-ı aşka cismini atmak diler her rûz ü şeb

Yüreği timürden olmak gerek itme aceb

Pâre pâre eylemiş cismin anun tîg-i kazâ

Ney gibi bağrı delinmiş bu imiş hükm-i Hudâ

Bu lügaz fethine açmak görinür üç yüz kitâb

Nermiyâ açmak gibidür bu dokuz eflāke bâb (Mecmû'a-yı Hafíza: v. 364a)

Nermî’nin aynı şekilde kurduğu bir lügazı da lisan, lügat ve lehçe gibi anlamlara gelen zebân kelimesi üzerindedir. Yukarıdaki iki örnekte olduğu gibi kelime hecelere bölünmüş ve art arda gelen iki kelimenin içinde geçirilerek verilmiştir.

Fe ilātün fe ilātün fe ilïn

Nedür ol ahsen-i takvîm-sûret

Dest ü engüştle bulmuş şöhret

Gûşına almaz idersey bin lâğ

Gerçi kim dil bilür eyler iblâğ

Sanma kâfir ola anı Müslim

Ki ola mâ'il-i zen yâ muğlim

Bir garîb turfe sadâsı vardur

Cilveli ucbe edâsı vardur

Gûşı var gerçi işitmez aslâ

Dili var anladamaz söz kat'â

Pür-ziyâ olsa cihân söylerler

Zulmet içinde sükût eylerler 
Söylese gördigini sâdıkdur

Şâhlar hıdmetine lâyıkdur

Remz ile bir lügaz itdüm imlâ

Nermiyâ ārif isen kıl ifşâ

Bize Bandırma'dan olursa gelür

Bu lügaz n'oldığını belki bilür (Mecmû'a-yı Hafîza: v. 346a)

Nermî lügazlarında ebced sisteminden de yararlanmıştır. Aşağıdaki lügaz basit bir ebced hesabıyla oluşturulmuştur:

\section{Fâilâtün fâilâtün fâilün}

Ol nedür kim bir bulınmaz nâm-dâr

Kendisi gözden nihân meydânı var

İsmi vardur cismi yok Ankâ gibi

Söylenür bir lafz-ı bî-manâ gibi

Lafzı üç harf ile mana rû-nümâ

Olmadı bîgânelerle âşinâ

Bulınur kâmil olan merdânda

Olsa da nâdir olur nisvânda

Bu lügaz dildârdan zâhir velî

İki kat olsa cefânun evveli (Mecmû'a-yı Hafîza: v. 280º

Lügazda cevabın, kendisinin bulunmamasına rağmen meydanı olan bir şey olduğu, Ankâ kuşu gibi adı var kendi yok bir nesne olduğu, adının anlamsız bir söz gibi söylendiği, üç harften oluştuğu, yabancılarda bulunmadığı, kâmil insanlarda olup unutkanlarda olmadığı gibi özellikleri verilmiştir. Bu ipuçları zihinde cevabı tam olarak şekillendirmez. Ancak son beyitte muhatabı cevaba götüren asıl ipucu bulunmaktadır.

Bu lügaz dildârdan zâhir velî

İki kat olsa cefânun evveli

Son dizede cefânın evvelinin yani başının iki kat olmasıyla kastedilen ebcedle ilgili yapılması gereken küçük bir değişikliktir. Bilindiği üzere ebced sisteminde belli bir kurala göre her harfin sayısal bir karşılığı vardır. Cefânın (جفا) evveli yani başı ج harfidir. Bu harfin ebceddeki sayısal değeri 3’tür. İki kat olması demekse cefanın başının 6 olması demektir. 6 rakamının ebceddeki karşıllğı ise و harfidir. ج harfini çıkarılıp yerine و harfini getirildiğinde ortaya lügazın da cevabı olan vefâ (وف) kelimesi çıar. 
Nermînnin bir lügazı bazı harflerin, cevap olan kelimeden çıkarılmasıyla oluşan yeni anlamların söylenmesi üzerinedir. Aşağıdaki lügazda kalem sorulmuştur:

Mefâîlün mefâîlün fe ûlün

Nedür ol kim kesersen başın anun

Yine baş gösterür gör işin anun

Kesersen ayă̆ını gayret eyler

Sana kes diyü söyler minnet eyler

Görinür pîşe şeklinde o gûyâ

Velî sanat bu kim tarh ola manâ

Lebi vasfinda kand olur perîşân

Bunı Nermî bilendür ehl-i irfân (Mecmû’a-yı Hafîza: v. 327ª)

İlk beyitte gizlenen nesnenin başının kesildiğinde yine baş çıkacağı ifade edilmektedir. Bilindiği gibi kalemin ucu köreldikçe yazma kalitesi düşer. Yazma kalitesini artırmak için uçu (başı), kalemtraş benzeri aletlerle kesilir. Böylece yeni bir baş çıkmış olur. Anlamsal olarak bu şekilde gerçekleşen olaya bir de kelimenin okunuşu itibarıyla bakılmalıdır. Kalem kelimesinin ilk harfi kaf yani "k" dir. Okuyuş olarak bu harf çıkarıldı̆̆ında geriye "alem" kelimesi kalır. Alem, minare ve bayrak direklerinin üzerindeki hilal biçimindeki tepeliğin adıdır yani bir çeşit baştır. İkinci beyitte lügazın cevabının ayağının kesilmesi durumunda gayret edeceği ve kes diye söyleyeceği ifade edilmektedir. Kalem kelimesinin ayağı mim harfidir. Bu harf kesildiğinde yani kalem kelimesinden çıkarıldığında geriye "kal" (söyleme, deme) ibaresi kalır. İkinci dizedeki "kes diye söyler" ifadesi ile bu kelime çağrıştırılmıştır. Sanatının çıkarılan mana olması, şeker kamışının dudağı vasfında kendini perişan etmesi (kamıştan yapılan kalemlere gönderme) ve irfan ehlinin bunu bilmesi ise kalemi çağrıştıran diğer ipuçlarıdır.

\section{Sonuç}

Lügaz, adı gizlenen bir nesnenin vasıflarını söylemek ve cevabı çă̆rıştırıcı remz ve imalarda bulunmak yoluyla muhataba, gizlenen nesneyi buldurmaya dayanan şiir türüdür. Başlangıçta bir söylem tarzı olan lügaz, Arap edebiyatında edebî bir tür haline gelmiş, İran edebiyatında da kullanılmıştır. Türk edebiyatına İran edebiyatından geçen lügaz, XV. yüzyıldan itibaren yaygın olarak kullanılmış, XVIII. yüzyılda ise en canlı dönemini yaşamıştır. Ahmed Paşa, Necati Bey, Fuzûlî, Bağdatlı Rûhî, Nâbî, Şeyh Gâlib ve Nedim gibi Klasik Türk edebiyatının önemli isimleri lügaz kaleme almışlardır.

Lügazlar temelde mana ve lafız lügazları olarak ikiye ayrılır: Adı gizlenene nesneyi vasıflarını söyleyerek buldurmaya çalışan lügazlar mana lügazları, adı gizlenen nesnede harf ve kelime oyunları yaparak ima ve işarette bulunarak cevabı buldurmaya dayanan lügazlar ise lafız lügazlarıdır. Lügaz yazmada başlangıçta kıta nazım şekli kullanılırken sonraları mesnevi nazım şekli ön plana çıkmış ve mevcut lügazların büyük bir kısmı bu nazım şekli ile kaleme alınmıştır. Yine fâilâtün fâ ilâtün fâiilün, fe il'âtün mefâiilün feilün/fa'lün ve mefâî̀iün mefâîlün fe ilün gibi nazım şekilleri lügaz yazmada en çok kullanılan vezinler olmuştur. 
Başlangıçta ok, kılıç, kalem, mum, kandil ve ev eşyası gibi somut nesneler lügazlarda sorulurken sonradan rüya, uyku gibi soYut kavramlar, tırnak kesmek gibi fiiller ve şahıs isimleri de lügaza konu olmuş, böylece lügazın konu alanı genişlemiştir.

Muamma lügaza çeşitli yönlerden benzeyen bir türdür. Muamma lügaz gibi gizlenen bir şeyin remz ve ima yoluyla muhataba sezdirilmesine dayanır. Ancak muammada gizlenen şeyin insan ismi olması lügazda ise insan ismi dışındaki nesneler olması, iki türü birbirinden ayırır. Bununla beraber insan isminin sorulduğu lügazlar da vardır. İki türün de manayı üstü kapalı olarak ifade etmesi lugaz ve muammayı birbirine yaklaştırmıştır. Lügaz yollu muammaların varlığı bu yakınlaşmanın somut bir örneğidir.

Lügaz, halk edebiyatında da kullanılmıştır. Ancak halk edebiyatında muamma ile karışmış, âşık tarzı halk şiirinde muamma asma geleneğinde ve bazı şair atışmalarında görülmüştür. Bunun yanında Âşık Ömer ve Âşık Sümmânî gibi şairler divanlarında lügaza yer vermişlerdir.

Çalışmanın konusu olan lügazların yazarı Nermî hakkında bilgi yok denecek kadar azdır. Eldeki tek bilgi bir halk şairi olduğudur. Bununla beraber Niğde-Bor kaynaklı bir cönkte Nermî mahlasıyla bir türkünün bulunması şairin bu bölgede yaşamış olabileceğini düşündürmektedir. Nermî’nin Mecmû'a-yı Hafîza adlı eserde 48 adet lügazı bulunmaktadır. Nermî bu lügazların büyük bir kısmını mesnevi nazım şekli ile ve fâilâtün fầilâtün fâilün vezniyle kaleme almıştır. Şair bazı lügazlarını mana lügazı olarak düzenlerken bazılarında da cevabı hecelere bölüp farklı kelimeler içinde geçirme, ebced hesabıyla cevabı işaret etme, cevabı başka bir kelimenin içinde geçirme, cevaptan harf çıkararak oluşan yeni anlamlara işaret etme gibi yollara başvurmuştur.

Şair, lügazlarını genellikle beş, sekiz ve yedi beyit olarak kaleme almıştır. Lügazlarında sade bir dil kullanmış, lügazlarını oluştururken kelimelerin Arapça Farsça karşılıklarından da yararlanmıştır. Şiirlerinde teşbih ve teşhis sanatlarına sıkça başvurmuştur. Şair, lügazlarında tencere, rebap, kebap, saz gibi somut varlıkları kullanırken vefâ örneğinde olduğu gibi soyut kavramlara da yer vermiştir.

\section{Kaynakça}

Ali Asgar Seyyid Gurâb (1954). "Seyr-i Tahvîl ü Karbendî Çistân der-Şii’r-i Farsî”, Bahş-ı İran-şinâsi Dânişgede-i Edebiyat, Dânişgâh-ı Liden, Sayı: 96.

Bilkan, Ali Fuat (1993). Nâbînnin Türkçe Divamı (Karşılaştırmah Metin), Gazi Üniversitesi Sosyal Bilimler Enstitüsü, Türk Dili ve Edebiyatı Bölümü, Doktora Tezi, Ankara.

Bilkan, Ali Fuat (2000). Türk Edebiyatında Muamma, Akçağ Yayınları, 1. Baskı, Ankara.

Bolat, Zekeriya (2006). Niğde-Bor Kaynaklı Kaynaklı 176 ve 177 Numaralı Cönkler Üzerine Tetkik, Niğde Üniversitesi Sosyal Bilimler Enstitüsü, Türk Dili ve Edebiyatı Anabilim Dalı Türk Halk Edebiyatı Bilim Dalı Yüksek Lisans Tezi, Niğde.

Çakır, Müjgan (2013). "Hayli Eglencedür Bu Rindâna: Arayıcızâde Ferdî Hüseyin ve Lügazları”, Divan Edebiyatı Araştırmaları Dergisi, Sayı: 11, s.127-176.

Çapan, Pervin (2005). “18.YY. Tezkirelerinde Örneklenen Mu'ammâ ve Lugazlar”, Osmanh Araştırmaları, XXVI, (Prof. Dr. Mehmet Çavuşoğlu’na Armağan-II), İstanbul, s.205-222.

Çelebioğlu, Âmil (1978). “Lugazlara Dâir”, Türk Kültürü, Yıl: XVII, Sayı: 193, s.43-47.

Demirkazık, H. İbrahim (2010), 'Mustafa Fennî’nin (ö.1745), Lugazlarının Özellikleri ve Divan'ında Olmayan Yedi Lugazının Tenkitli Metni”, Divan Edebiyatı Araştırmaları Dergisi, Sayı: 5, s.3580.

Durmuş, İsmail (2003). “Lugaz”, Türkiye Diyanet Vakfi İslam Ansiklopedisi, C. 27, Ankara, s. 221-222. 
Ebû Muhammed Abdullah b. Müslim b. Kuteybe Dineveri İbn Kuteybe, Eş-Şi’r ve’ş-Şuara, C.1, Darü’sSekafe, Beyrut- Lübnan.

Elçin, Şükrü (1993). Halk Edebiyatına Giriş, Akçağ Yayınları, Ankara.

Erkali Abdülkadir (2015). Âşık Sümmânî Dîvânı, Erzurum Büyükşehir Belediyesi Yayınları, Erzurum.

Fahuri, Hanna (1964). Divan-ı İmrü'l-Kays, Beyrut: Dârü'l-Cil, 1989.

Gürçayır teke, Selcan, "Nermî (d. ?/ö. ?) " Türk Edebiyatı İsimler Sözlüğü, ,23.09.2013,http://www.turkedebiyatiisimlersozlugu.com/index.php?sayfa=detay\&detay=1084. [Erişim Tarihi: 12.01.2020]

Karasoy, Yakup ve Yavuz Orhan (2015). Âşık Ömer Divanı, Konya Büyük Şehir Belediyesi Kültür Yayınları, 1. Baskı, Konya.

Köprülü, Mehmet Fuat (1989). Edebiyat Araştırmaları 1, Ötüken Neşriyat, 3. Baskı, İstanbul.

Mecmû’a-yı Hafiza (Mecmû’a-yı Eş’âr ve Elgâz), (Müellif: Sıdkî Mustafa), Millet Kütüphanesi, AE Mnz $567,400 \mathrm{v}$.

Nureddin Muhammed b. Muhammed b. Yahya Buhârî, Avfî, Lübâbü’l-elbâb (1906). (ed. Edward G. Brown, Mirza Muhammed), Leiden : E. J. Brill; London: Luzac \& Co., C.1.

Savran, Ahmet (2000). “İmrü'l-Kays B. Hucr”, Türkiye Diyanet Vakfi İslam Ansiklopedisi, C. 22, İstanbul.

Sezen gönenç, Cevriye (2011). Âşı Tarzı Türk Şïrinde Muamma ve Lugaz, Fatih Üniversitesi Sosyal Bilimler Enstitüsü, Türk Dili ve Edebiyatı Anabilim Dalı, Yüksek Lisans Tezi, İstanbul.

Toprak, M. Faruk, (2001). “Klasik Arap Şiirinde Luğaz”, Nüsha Dergisi, Yıl: 1, Sayı:3, s.97-110.

Usta, İbrahim (2009). “Arap Literatüründe 'Luğaz / Elğâz’ Kültürü”, The Journal of Academic Social Studies, 2/1, s.89-99.

Uzun, Mustafa İsmet (2003). “Lugaz”, Türkiye Diyanet Vakfi İslam Ansiklopedisi, C. 27, Ankara, s.222223.

Toprak, M. Faruk (2001). “Klasik Arap Şiirinde Luğaz”, Nüsha Dergisi, Yıl: 1, Sayı:3, s.97-110. 